\title{
The relationship between climate change and wars waged between nomadic and farming groups from the Western Han Dynasty to the Tang Dynasty period
}

\author{
Y. Su${ }^{1}$, L. Liu ${ }^{1}$, X. Q. Fang ${ }^{1}$, and Y. N. Ma ${ }^{1,2}$ \\ ${ }^{1}$ School of Geography, Beijing Normal University, Beijing, China \\ ${ }^{2}$ Sun Yat-Sen Memorial Middle School, Zhongshan, Guangdong Province, China \\ Correspondence to: Y. Su (suyun@bnu.edu.cn) \\ Received: 13 June 2015 - Published in Clim. Past Discuss.: 31 July 2015 \\ Revised: 22 November 2015 - Accepted: 5 January 2016 - Published: 29 January 2016
}

\begin{abstract}
In ancient China, shifts in regional productivity of agriculture and animal husbandry, caused by climate change, either led to wars or peaceful relations between nomadic and farming groups. During the period spanning the Western Han Dynasty to the Tang Dynasty, 367 wars were waged between these groups. While $69 \%$ of the wars were initiated by nomads, $62.4 \%$ were won by the farming groups. On a centennial timescale, the battlegrounds were mostly in northern areas (at an average latitude of $38.92^{\circ} \mathrm{N}$ ) during warm periods, moving southward (at an average latitude of $34.66^{\circ} \mathrm{N}$ ) during cold periods. On a decadal timescale, warm climates corresponded to a high incidence of wars (a correlation coefficient of 0.293). While farming groups were inclined to initiate wars during dry and cold periods, their chances of achieving victory were reduced at such times. The main reasons for this are, first, that a warm climate provided a solid material foundation for nomadic and farming groups, contributing especially to enhanced productivity among the former. However, the overriding desire of nomadic groups to expand essential subsistence means led to wars. Second, during cold periods, farming groups moved to and settled in the south, while nomadic groups occupied the Central Plain. Thus, the locations of the battlefields also changed. While other factors also influenced these wars, climate change served as a backdrop, playing an indirect role in wars between these groups.
\end{abstract}

\section{Introduction}

The association between violent conflicts and environmental change has attracted much attention recently. Since 2007, more systematic research on the effect of climate change on security issues has emerged. The theoretical model linking climate change to intrastate conflict incorporates case studies as well as conflict statistical studies. Three effects of climate change (natural disasters, sea-level rise, and increasing scarcity of resources) may lead to loss of livelihood, economic decline, and increased motivation for instigating violence (Buhaug et al., 2008). Climate change is a contributing factor to conflict (Collier and Hoeffler, 2005; Homer-Dixon et al., 1993; Maxwell and Reuveny, 2000), acting in many cases as a "threat multiplier" (CNA, 2007). The latest research, published in Science in August 2013, has found that even minor changes in climate are linked to increases in violence and warfare in human populations (Hsiang et al., 2013).

The key factors in conflicts stemming from climate change vary from region to region. Webster's study of historical societies suggested that warfare is an adaptive ecological choice under the conditions of population growth and resource limitation (Webster, 1975). In Africa, most studies of influencing factors have focused on the role of precipitation in explaining the incidence of conflict, finding that modern conflicts are more likely in drier years or during prolonged droughts (Held et al., 2006; Hendrix and Glaser, 2007). Over the last millennium, conflicts were more prevalent during colder periods not only in Europe (Tol and Wagner, 2010) but also in China (Zhang et al., 2006) because reduced thermal energy 

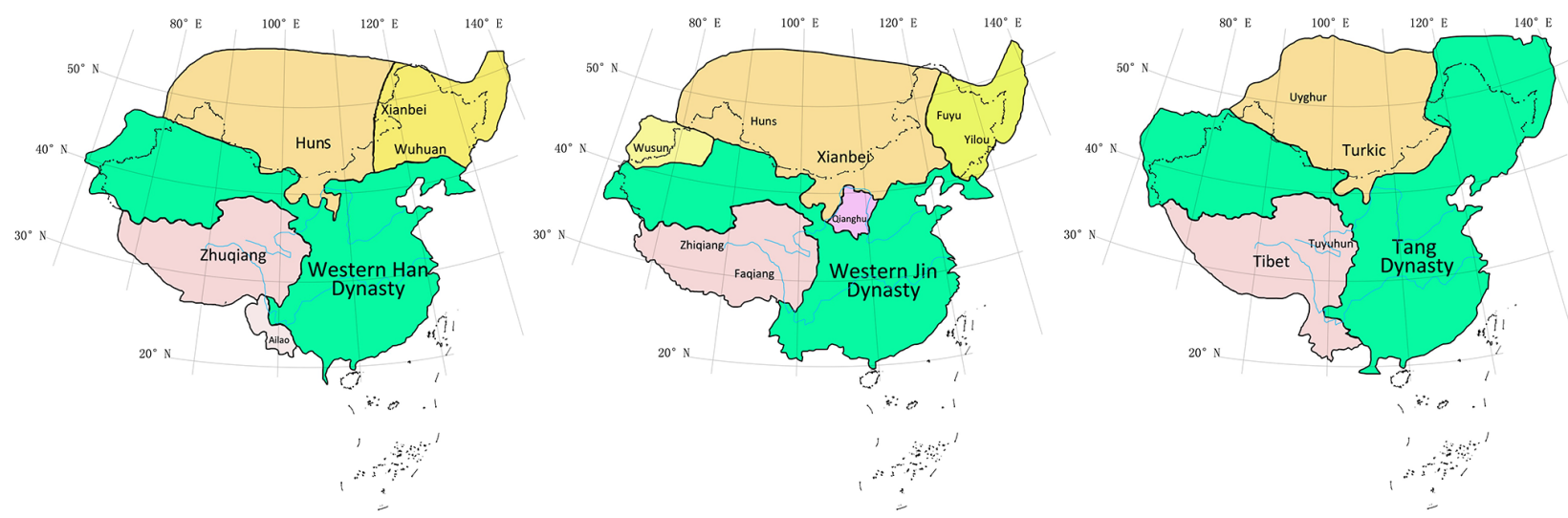

Figure 1. Distribution of the regions of the nomadic and farming groups during the Western Han Dynasty, the Western Jin Dynasty, and the Tang Dynasty (Tan, 1982). Note: regions in which farming groups became established in different periods are in green. Regions identified with other colours correspond to different systems established by several nomadic ethnicities.

input during a cold phase lowers the land-carrying capacity in a traditional agrarian society.

The impact process of climate change on conflict varies in different regions. Zhang et al. (2006) concluded that in China the frequency of war varied in the last millennium according to geographical locations (northern central vs. southern China) because of differences in the physical environment and hence differential responses to climate change. This study also concluded that variations in the frequency of rebellion in China were highly correlated with climatic changes. The conflicts were more prevalent during colder periods. However, in northern China, the anomalous peaks, overshadowed by this correlation, were mainly due to the instigation of conflict by nomadic invaders from the north (Zhang et al., 2006). This leads to the question of whether conflicts are more prevalent during colder periods when factors relating to regional divisions or types of violent conflicts are considered. This paper focuses on the relationship between climate change and wars of invasion between nomadic and farming groups in northern China in 206 BC-AD 906.

Rotational grazing and sedentary farming were two of the most important modes of economic production in ancient societies. These subsistence techniques gave rise to two groups: nomadic and farming groups. The nomadic group comprised a number of nomadic minorities, such as the Huns, Xianbei, Xiqiang, Khitan and Turks. The farming group was predominantly of Chinese Han ethnicity and was a combination of ancient Huaxia people and other ethnic groups. The main tribes of the Huaxia were the Huang Di, Yan Di, and Chi You. The history of the exchange and conflicts between these two groups is an important part of Chinese civilisation (Shu and Xiao, 2008). In China, the northern nomadic tribes moved from place to place in search of water and grass for their herds. Nomadic settlements in the vast temperate arid or semi-arid steppes had to content with harsh conditions: cold temperatures in winter and infrequent rainfall. In con- trast, the farmers, mainly of Chinese Han ethnicity, adopted a self-sufficient way of production and spread across the eastern monsoon region, where the rainfall and high temperatures occurred at the same time, with relatively abundant precipitation. The natural climate conditions in these areas were comparatively favourable (Fig. 1). Therefore, the farming group was mainly engaged in agricultural production and living a sedentary life.

The evolution of inter-group relations in China has a long and complex history, which, when combined with long-term historical documentation, is facilitates relationship studies between climate change and group conflicts. Hinsch (1998) referred to climate change in eastern Asia, Europe, and North America and discussed the relationship between Chinese history and different climate change periods. He pointed out that China was traditionally an agrarian society, which was particularly vulnerable to the effects of climate change. He also summarized the periodic alternations between warm and cold periods in China and described the competition and integration of the ecological environment of the nomadic and farming civilisation. Based on the ancient administrative divisions in the Historical Atlas of China (Tan, 1982), Wang Huichang studied the latitude change in the southern boundary of the national system of government established in the southward migration process of the northern nomadic groups, starting with the Qin and Han dynasties. From this, he concluded that in warm periods, the nomadic and farming groups maintained a peaceful relationship, while in cold periods, the nomads moved southward, leading to instability of the Central Plain system and confrontations between the two groups (Wang, 1996).

Research on the relationship between climate change and different community group relations should involve not only empirical cases but also the construction of proxy indicators and sequences. By conducting quantitative studies, we can better understand the impact of climate change. How- 
ever, because the evaluation of different community group relations is complicated, there is a lack of reconstructions of long-term, continuous community group relation sequences with a high resolution.

The period which this paper examines (206 BC-AD 906) spanned 1112 years and gave rise to eight major dynasties. The Western Han Dynasty (206 BC-AD 24), the Eastern Han Dynasty (AD 25-220), the Western Jin Dynasty (AD 265316), the Sui Dynasty (AD 581-617), and the Tang Dynasty (AD 618-906) managed to unite the region by politically ruling both the southern and northern parts of China. In contrast, during the Three Kingdoms (AD 220-280), the Eastern Jin Dynasty (AD 317-420), and the Southern and Northern dynasties (AD 420-589, and 386-581, respectively), China was in turmoil. In the Eastern Han Dynasty and the Southern and Northern dynasties, nomadic groups conquered the Central Plain and occupied the northern part of China. This paper focuses on the period from the Western Han Dynasty to the Tang Dynasty, constructs the sequence of the interethnic wars at this time based on historical documents, and compares this sequence with that of simultaneous climate changes to analyse the influence of climate change on these wars.

\section{Data and methods}

\subsection{Reconstruction of the sequence of wars between nomadic and farming groups}

To exchange and acquire natural resources and products, nomads and farmers have historically traded with each other, leading to migration, population mixing, and even cultural blending of these groups. However, there have also been disputes, conflicts, and wars between them. National cohesion was ultimately achieved either through peaceful communication or conflicts between nomadic and farming groups.

Data on the wars that occurred between nomadic and farming groups in China were obtained from the Chronology of Wars in Chinese History (The Chinese Military History editorial board, 2003), which was compiled and edited by the Chinese Military History group at the Nanjing Academy of Military Sciences. The primary chronological data sources were the Twenty-Four Histories ${ }^{1}$ and the Draft of the History of the Qing Dynasty ${ }^{2}$. These two sets of volumes are widely regarded as authoritative sources of traditional Chinese history and culture. Uniform standards for selecting and

\footnotetext{
${ }^{1}$ The Twenty-Four Histories is a general term describing 24 historical books chronicling China's official history, excluding the Qing Dynasty, which has generally been written about and reviewed independently by later dynasties. The Twenty-Four Histories comprise the Records of the Historian, the Book of Han, the Book of Later Han, and so on.

${ }^{2}$ The Draft of the History of the Qing Dynasty is a draft of the official history of the Chinese Qing Dynasty, written in 1927 and comprising 536 volumes.
}

recording wars have been applied in the Chronology. In addition, the Chronology contains records of causes, processes, results, and characteristics of major wars. Thus, the information source on wars is reliable. However, many factors influence historical records and the inheritance and transmission of books. For example, during periods of war, historical records were reduced. The burning of books has also occurred in Chinese history. Consequently, there are contrasting periods, some characterized by especially rich records and some by sparse records (Zhang, 2002). In other words, there is discontinuity and heterogeneity in the historical records (Fig. 2). As a result, during periods of discontinuous historical records, there is a shortage of war records, leading to the underestimation of the frequency of war. According to the statistics, such periods entailing a lack of records amount to a total of 56 years, accounting for $5 \%$ of the entire period.

Based on the records contained in the Chronology, we classified and selected 367 wars waged between nomadic and farming groups extending from the Western Han Dynasty to the Tang Dynasty. We noted the following information: the year when a war occurred, the name of the war, the initiator, the victor, the major battlefield, and its location (its present name and position by latitude and longitude).

The selection of the records was based on the following criteria.

1. We only included wars waged between northern nomadic groups and established agricultural groups in central China. We excluded the following: wars between nomadic ethnic groups or tribes, wars between nomadic and separatist groups, peasant uprisings against agricultural groups in the Central Plain, and wars between minority ethnic groups in southwestern China and farmers or foreign countries.

2. If the duration of a war was more than 1 year, the initial year was recorded according to details provided in the Chronology.

3. In 363 records (accounting for $98.91 \%$ of the compiled data), it was clear who had initiated the war. However, in four records $(1.09 \%)$, farming groups provided assistance (in the form of troops) to nomads embroiled in civil strife. In these instances, the farming groups were regarded as the initiators.

4. In 355 records $(96.72 \%)$, it was clear who the victors were. However, in 12 records, the victors were not identified. One side was referred to as an "effective defense" or "effective counterattack" in seven $(1.91 \%)$ of these records. The opposing side was correspondingly described in terms such as "unable to conquer the adversaries" or "attempted attack failed." In these records, the defending side was categorised as the victor. In three records $(0.82 \%)$, one side asked for a truce or made peace through marriage and was deemed the losing party. Two other records $(0.54 \%)$ pertained to wars 


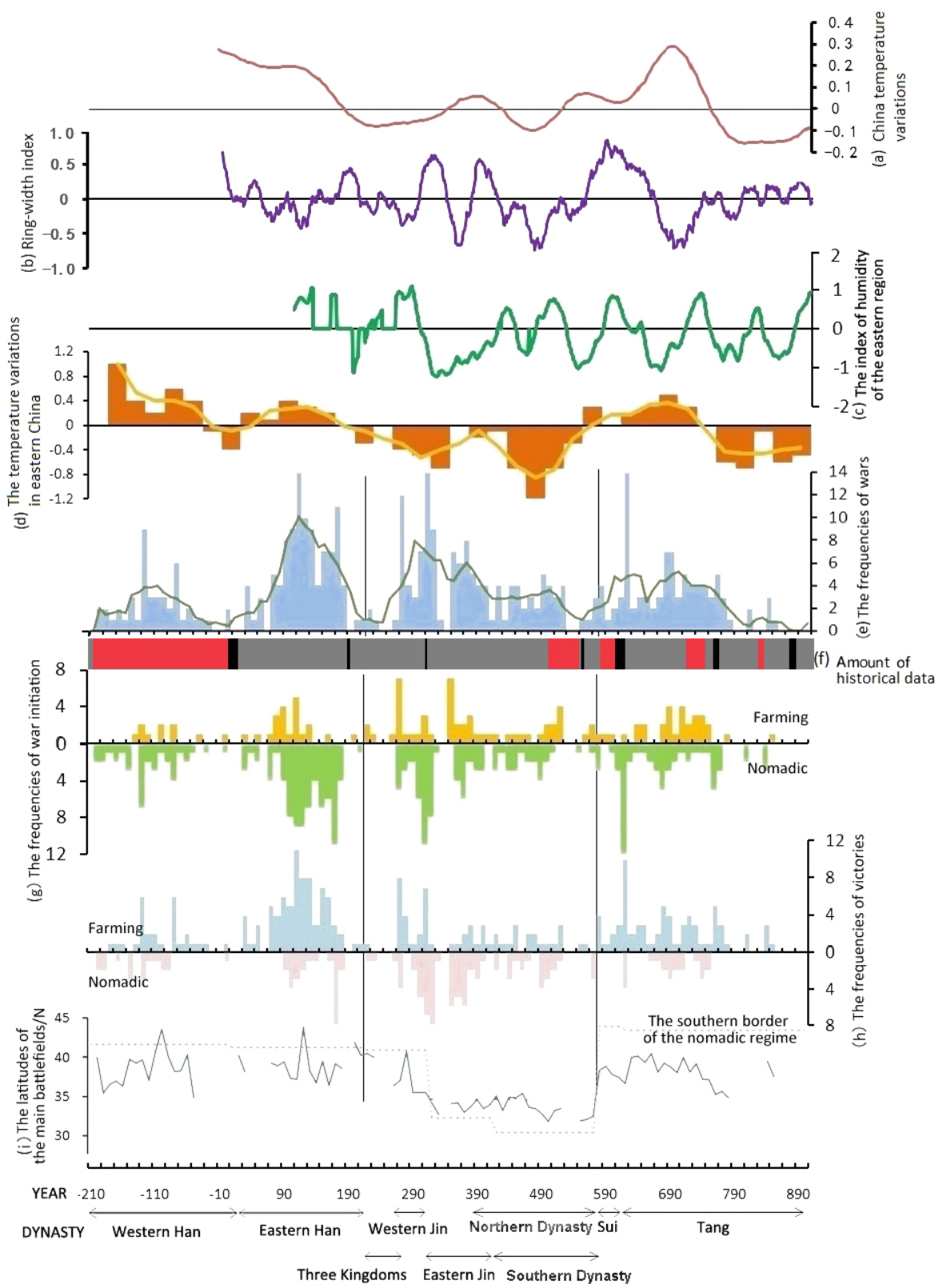

Figure 2. Sequence of wars between the northern nomadic and farming groups. Panel (a): China temperature variations during AD 1-910. Ensemble temperature reconstructions based on partial least squares (PLS) methods at centennial timescales (smoothed by a 5-point fast Fourier transform (FFT) filter) (Ge et al., 2013); panel (b): ring-width index with 31-year moving averages from the northeastern QinghaiTibetan Plateau (Shao et al., 2010); panel (c): annual humidity index of China from AD 105 to 910 (smoothed by a 31-point FFT filter) (Zheng et al., 2006); panel (d): temperature variations in eastern China and three-point moving average curve for winter half-years during 200 BC-AD 910 (30-year period timescale) (Ge et al., 2003, 2010); panel (e): frequency of war and five-point moving average values (green solid line); panel (f) number of historical records - red indicates a rich phase in the historical data, grey indicates plentiful data, black regions indicate breaks in the data record (Zhang, 2002); panel (g): frequency of wars initiated by the farming and nomadic groups; panel (h): frequency of victories of farming and nomadic groups; panel (i): latitude of the main battlefields (N, blue solid line), changes in the southern border of the nomadic region in each dynasty (green dotted lines) (Wang, 1996).

entailing multiple battlefields and varying outcomes of different wars. In these records, we classified the outcomes according to the war that was waged last.
5. The location of the war was available in 351 records $(95.64 \%)$. However, no relevant information was available for two specific situations, for which we consequently used other criteria. In 11 records $(1.99 \%)$ the 
battlefield location was noted as being "on the border". In such situations, we referred to the Historical Atlas of China (Guo, 1996) using the midpoint of the border as the battlefield location. In five other records $(1.36 \%)$, where the only details provided were of the armies involved, we used the locations of army camps as the battlefield locations.

We calculated the total number of wars, the average latitudes of the battlefields, the frequency of conflict initiation by nomadic versus farming groups, and the proportion of each group's victories on a decadal timescale. Consequently, we reconstructed the series of wars spanning the period extending from the Western Han Dynasty to the Tang Dynasty. Based on our analysis of the variation characteristics of the sequences, we divided the historical periods into several stages. We plotted the distribution of major battlefields as a scattergram and performed a spatial analysis of the distribution of the conflict regions. We further assessed whether there was a possible relationship between the wars and climate change using decadal and centennial timescales.

\subsection{Climate change sequences}

To improve the reliability of our sequence comparison, we used temperature and precipitation as the comparative references for two sequences each.

The following two temperature sequences of other scholars were used.

1. Reconstructed temperature data, based on historical documents, indicate a series of temperature variations during the winter half-year in eastern China over the last 2000 years (Ge et al., 2003, 2010). This reconstruction was based on the pioneering research of Chu (1973), whose historically reconstructed series on China's climate change are widely accepted (Gribbin, 1973). Temperature variations for the winter half-year (OctoberApril), in relation to the mean value calculated for the period 1851-1950, were constructed using a 30-year timescale resolution. These were based on historical documents that provided details on agricultural production. Results obtained for eastern China (east of $105^{\circ} \mathrm{E}$, $25-40^{\circ} \mathrm{N}$ ) indicated temperature variations in the farming regions.

2. A composite series reconstructed by Ge et al. (2013), based on partial least squares regression, shows the occurrence of temperature variations, at a decadal resolution, over the last 2000 years in China. The mean temperature from 1851 to 1950 was applied as a reference value. To reconstruct a temperature anomaly series for China, Ge et al. (2013) selected 28 published proxy temperature series. The proxies included sediments, stalagmites, historical documents, tree rings, and ice cores. A nationwide reconstruction was developed using proxy temperature data with relatively high confidence levels for five regions (the northeast, northwest, central east, Tibetan Plateau, and southeast).

For the dry / wet ratio series, we used two sequences for comparative purposes as follows.

The first series, constructed by Zheng et al. (2006), was a dry / wet ratio series of eastern China over the last 1500 years. This series covers the period from AD 105 to 2000 in eastern China (extending to northern China, the Yangtze-Huai He region, and the Jiangnan area). The series was reconstructed by applying the drought and flood grades of 48 sites based on Chinese historical records. It indicates changes in dryness and wetness in farming regions. Positive values refer to higher precipitation and negative values refer to lower precipitation.

The second series, constructed by Shao et al. (2010), focuses on the ring-width index with 31-year moving averages for the northeastern Qinghai-Tibetan Plateau. The QinghaiTibetan Plateau is a region sensitive to recent global climate change. The tree-ring-width chronology of Qilian juniper indicates precipitation changes and can reflect changes in humidity in western China. Positive values refer to higher precipitation and negative values refer to lower precipitation.

\section{Analysis}

\subsection{War sequences between nomadic and farming groups}

\subsubsection{War frequency}

A total of 367 wars (an average of 3.3 wars decade ${ }^{-1}$ ) were waged between agricultural and nomadic groups, spanning the period from the Western Han Dynasty to the Tang Dynasty (Fig. 2). The wars fought between these two groups were concentrated during different periods. Wars were more frequent (14 wars decade ${ }^{-1}$ ) during three periods (AD 111120, 311-320, and 621-630) compared with other periods. Based on the descending order of the frequency of war during each dynastic period, the top $15 \%$ of periods (with frequency $\geq 7$ wars decade ${ }^{-1}$ ) was categorised as high-incidence periods. There were 18 such periods involving 169 wars. In other words, $46 \%$ of all the wars occurred during $16 \%$ of the entire timespan (1112 years). The periods during which the frequency of war was 1 or less per decade, were regarded as low-incidence periods. During these 41 periods, only 20 wars occurred (covering $36 \%$ of the time span and $5 \%$ of the total wars). Periods without wars mainly occurred during the late period of a dynasty or between dynasties in the Central Plain when surplus power for initiating wars or resisting enemies was lacking. However, records were lacking for the period of dynastic succession.

A statistical classification of wars during different dynastic periods suggests that decadal war frequencies during the Eastern Han, Western Jin, and Eastern Jin dy- 
nasties were considerably above the average frequency (3.3 wars decade ${ }^{-1}$ ) and that there was a high incidence of wars during these dynastic periods (Table 1). A total of 14 high-incidence periods of war occurred during the timespan of these three dynasties, accounting for $78 \%$ of all the highincidence periods. During other dynastic periods, the decadal frequency of war was below the average. These were, therefore, considered low-incidence periods.

\subsubsection{Initiators and victors of war}

Table 2 shows the frequency of war initiation and victory for farming and nomadic groups. Initiators of war were predominantly nomadic groups while war victors were predominantly farming groups. This distribution was particularly marked for politically unified dynasties (the Western Han, Eastern Han, Sui, and Tang dynasties). During the Western and Eastern Han dynastic periods, farming groups initiated far fewer wars but were mostly victorious. This pattern persisted until the Sui and Tang dynasties, during which the number of wars initiated by farming groups was slightly increased; again, they largely remained victorious. Conversely, nomadic groups were the primary instigators of war, achieving victories only during periods of political turbulence (i.e., during the Western Jin, Eastern Jin, Southern, and Northern dynasties). However, most of the wars that occurred during the era of the Three Kingdoms were initiated by farming groups, who achieved few victories.

\subsubsection{Classification of war periods}

We divided the series into three periods based on the frequency of war and the distribution of the conflict regions during different dynastic periods (Fig. 2). The first period comprised the periods of the Western and Eastern Han dynasties (206 BC-AD 220). There was a low incidence of wars at the beginning of this period (the Western Han Dynasty) and a high incidence of wars towards the end of the period (Eastern Han). There were 148 wars ( $40 \%$ of the total), with an average of 3.4 wars decade ${ }^{-1}$, increasing to 5.3 wars decade $^{-1}$ during the Eastern Han period. Farming groups initiated and won 21.6 and $71.6 \%$, respectively, of the conflicts that occurred during this period.

The second period encompassed the Three Kingdoms and the Wei, Jin, Southern, and Northern dynasties (AD 221580). During this period, 130 wars occurred (36\% of the total and 3.6 wars decade ${ }^{-1}$ ). The frequency of wars initiated by farming groups was significantly higher during this period (38.5\% of the total) compared with farmer-group-initiated wars during the earlier period. However, this group achieved only $42.3 \%$ of the total victories.

The third period, comprising the Sui and Tang dynasties (AD 581-906), was a low-incidence period for wars. During this period, there were 89 wars in total $(24 \%$ of the total and 2.7 wars decade ${ }^{-1}$ ). Apart from the high incidence of wars during the transition periods of different dynasties, there was an overall decrease in the war frequency. Farming groups initiated fewer conflicts ( $34.8 \%$ of the total) but won the majority $(76.4 \%)$ of these.

\subsection{The distribution of and shifts in the location of conflicts between farming and nomadic groups}

The main combatants in wars that occurred during the first period (206 BC-AD 220) comprised an ethnic group (e.g., the Huns, Qiang, Xianbei, or Wuhuan) and the farming social groups who established the Western and Eastern Han dynasties. The border between the territories of the Huns, Wuhuan, and Xianbei ethnic groups and that of the Han Dynasty was located at approximately $44^{\circ} \mathrm{N}$, and extended southeast to $41^{\circ} \mathrm{N}$ (Guo, 1996). The main conflict regions were located from 33 to $42^{\circ} \mathrm{N}$ and from 100 to $118^{\circ} \mathrm{E}$. They were distributed along the Hexi Corridor and on the Loess Plateau, south of the Yellow River and north of the Qin Ling (highincidence regions); in regions to the east of the Hetao Plain and to the west of the Taihang Shan (high-incidence regions); and in regions adjoining the Great Wall north of the North China Plain. In summary, the major battlefields were mostly located in border regions (Fig. 3a).

During the second period (AD221-580), wars mainly broke out between the Xianbei ethnic group or the Hun Dynasty and the Western Jin Dynasty, as well as between the Eastern Jin Dynasty and the nomadic tribes that invaded the North China Plain (commonly known as the Central Plain). During the period of the Western Jin Dynasty, the border between the two groups extended from the northeastern part of the Tian Shan and Hexi Corridor, north of the Qin Ling $\left(36^{\circ} \mathrm{N}\right)$, along the Yellow River and up to the Great Wall of that time $\left(40^{\circ} \mathrm{N}\right)$. During the period of the Eastern Jin Dynasty, the border was located near the Qin Ling and the Huai He River at around $33^{\circ} \mathrm{N}$ (Guo, 1996). The main battlefields were situated at $105-120^{\circ} \mathrm{E}$ and $30-38^{\circ} \mathrm{N}$, scattered along the Qin Ling, the North China Plain, and the area west of the Shandong Peninsula (Fig. 3b).

Wars that occurred during the third period (AD 581-906) were mainly fought between nomadic groups such as the Tuyuhun, Turks, Khitan, Tibetan, and Uighur tribes, on the one hand, and the Sui and Tang dynasties, on the other hand. The border between the territories of minorities in the north and the dynasties located on the North China Plain passed through the $42^{\circ} \mathrm{N}$ line of latitude (Guo, 1996). The conflicts were widely distributed within a range of $98-113^{\circ} \mathrm{E}$ and $33-42^{\circ} \mathrm{N}$, mainly in the northwestern region. Furthermore, some of the wars extended to present-day Kazakhstan and Kyrgyzstan, with sites scattered across the Tian Shan, the Hexi Corridor (high-incidence regions), and the Loess Plateau south of the Yellow River and north of the Qin Ling; across regions east of the plain and west of the Taihang Shan; and across regions adjoining the Great Wall north of the North China Plain (Fig. 3c). 
Table 1. Frequency of wars between the farming and nomadic groups from the Western Han Dynasty to the Tang Dynasty in China.

\begin{tabular}{lrrc}
\hline Dynasty & Total & $\begin{array}{r}\text { Frequency } \\
\text { (times decade }^{-1} \text { ) }\end{array}$ & High-frequency periods \\
\hline Western Han & 46 & 2.00 & 130s BC \\
Eastern Han & 102 & 5.28 & AD 90-130s; AD 150-170s \\
Three Kingdoms & 3 & 0.66 & \\
Western Jin & 38 & 7.45 & AD 270s; AD 300-320s; AD 350s \\
Eastern Jin & 48 & 4.66 & AD 370s \\
Southern and Northern & 41 & 2.43 & \\
Sui & 9 & 2.50 & AD 620s; AD 680-690s \\
Tang & 80 & 2.78 & \\
\hline Sum (first column) and average (second column) & 367 & 3.30 & \\
\hline
\end{tabular}

Table 2. Frequency of war initiation and victories of the farming and the nomadic groups.

\begin{tabular}{|c|c|c|c|c|c|c|c|c|}
\hline \multirow[b]{2}{*}{ Dynasty } & \multicolumn{4}{|c|}{ Farmers } & \multicolumn{4}{|c|}{ Nomads } \\
\hline & $\begin{array}{r}\text { Total } \\
\text { initiation }\end{array}$ & $\begin{array}{c}\text { Percentage } \\
(\%)\end{array}$ & $\begin{array}{r}\text { Total } \\
\text { victories }\end{array}$ & $\begin{array}{c}\text { Percentage } \\
(\%)\end{array}$ & $\begin{array}{r}\text { Total } \\
\text { initiation }\end{array}$ & $\begin{array}{c}\text { Percentage } \\
(\%)\end{array}$ & $\begin{array}{r}\text { Total } \\
\text { victories }\end{array}$ & $\begin{array}{c}\text { Percentage } \\
(\%)\end{array}$ \\
\hline Western Han & 11 & 23.91 & 28 & 60.87 & 35 & 76.09 & 18 & 39.13 \\
\hline Eastern Han & 21 & 20.59 & 78 & 76.47 & 81 & 79.41 & 24 & 23.53 \\
\hline Three Kingdoms & 3 & 100 & 1 & 33.33 & 0 & 0 & 2 & 66.67 \\
\hline Western Jin & 11 & 28.95 & 19 & 50 & 27 & 71.05 & 19 & 50 \\
\hline Eastern Jin & 19 & 39.58 & 16 & 33.33 & 29 & 60.42 & 32 & 66.67 \\
\hline Southern and Northern & 17 & 41.46 & 19 & 46.34 & 24 & 58.54 & 22 & 53.66 \\
\hline Sui & 3 & 33.33 & 9 & 100 & 6 & 66.67 & 0 & 0 \\
\hline Tang & 28 & 35 & 59 & 73.75 & 52 & 65 & 21 & 26.25 \\
\hline $\begin{array}{l}\text { Totals (initiation) } \\
\text { and averages (percentages) }\end{array}$ & 113 & 30.8 & 229 & 62.4 & 254 & 69.2 & 138 & 37.6 \\
\hline
\end{tabular}

An overall examination of these periods revealed that the battlefields were mainly distributed over the Hexi Corridor, the Loess Plateau south of the Yellow River and north of Qin Ling, and throughout the entire North China Plain. These regions adjoined those of nomadic and farming groups located in the semiarid ecological transitional band on the fringes of agricultural production areas. The location of this region corresponds to that of the $400 \mathrm{~mm}$ isohyets, demarcating monsoon and non-monsoon regions, and the regions along the Great Wall, all of which are extremely sensitive to climate change.

The battlefields during the first period (the Western and the Eastern Han dynasties) and the third period (the Sui and Tang dynasties) were located mainly in the north, at a considerable distance from the capitals of the agriculturalist governing groups. Conversely, the battlefields during the second period (the Three Kingdoms, the Western and Eastern Jin dynasties, and the Southern and Northern dynasties) were located near the capitals of the agricultural areas and even occupied the capitals (Luoyang, Chang'an, etc.).

\subsection{Impact of the climate on ethnic wars}

\subsubsection{Climate change from the period of the Western Han Dynasty to that of the Tang Dynasty}

Ge et al. (2013) made the following observations in relation to changes in temperature variations in China. First, warm periods occurred from $200 \mathrm{BC}$ to AD 180 (during the Western and Eastern Han dynasties) and AD 541-760 (the Sui Dynasty and up to the middle of the Tang Dynasty). Second, there were two cold periods in AD 181-540 (the Wei and Jin dynasties and the Northern and Southern dynasties) and AD 761-910 (the late Tang Dynasty). Moreover, while temperature changes in the eastern farming area occurred in parallel with those in the country as a whole (Ge et al., 2003, 2010), there were differences in the range of temperature changes. Such differences were caused by regional temperature differences. Regional differences were evident during the following periods: AD 271-360, 451-570, and 781-840. During these periods, temperature variations in eastern China were lower than those in the rest of country. For example, while the period from AD 450 to 570 was relatively cold in 

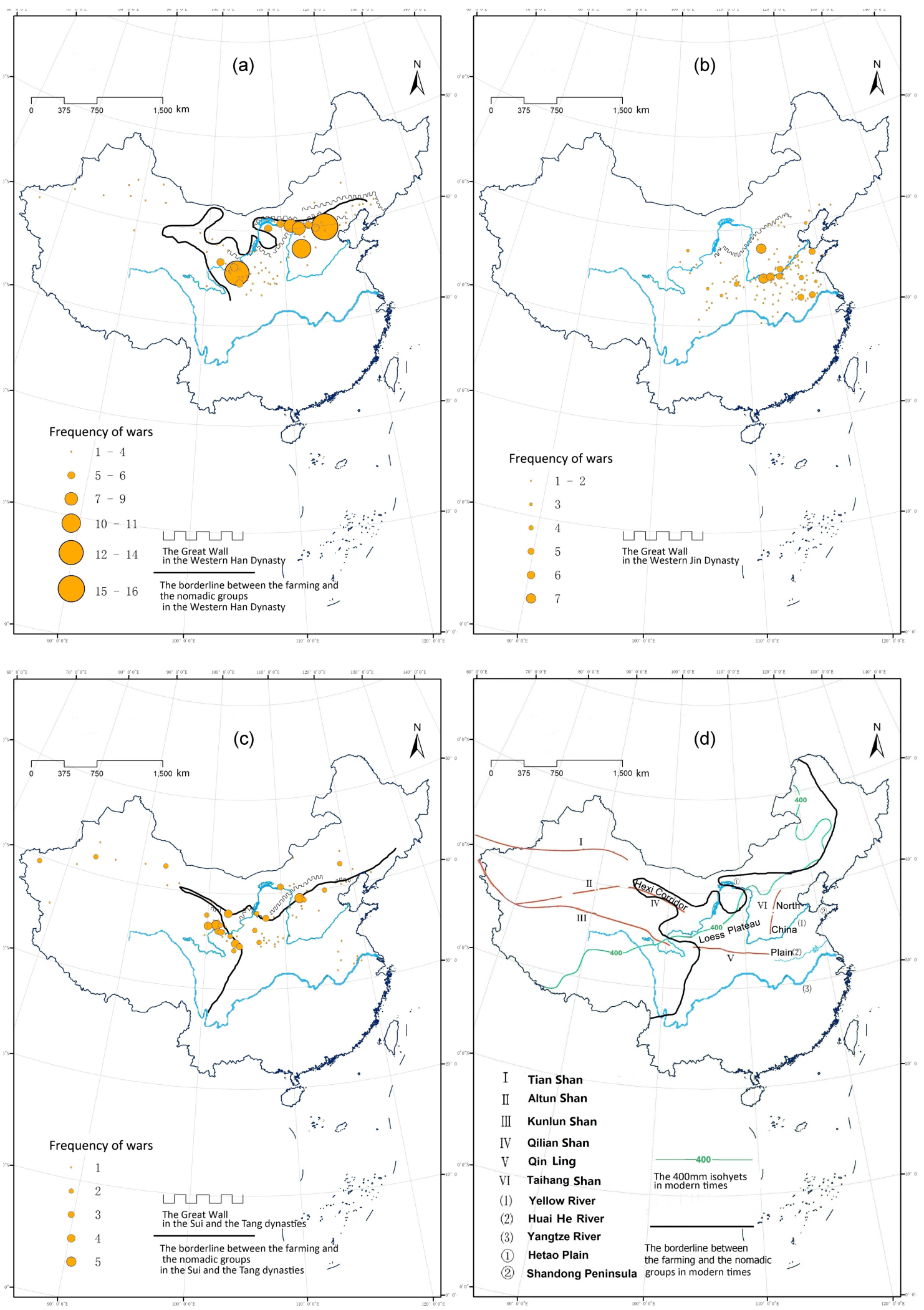

Figure 3. Distribution of ethnic wars in different periods (panel a: 210 BC-AD 220; panel (b): AD 221-580; panel (c): AD 581-906) and basic geomorphology units (d) in China. 
the eastern region, it was the warmest century, historically, in the northeastern region (Hong et al., 2000; Chu et al., 2012).

On a centennial timescale, China's temperature fluctuation paralleled that of the Northern Hemisphere. The temperature sequences of the Northern Hemisphere have been reconstructed by a number of scholars (Loehle, 2007; Loehle and McCulloch, 2008; Mann et al., 2008, 2009; Ljungqvist, 2010; McShane and Wyner, 2011; Christiansen and Ljungqvist, 2012). Most of these sequences indicate that warm periods occurred from AD 1 to 270 and from AD 841 to 1290 , while there were alternate warm and cold periods from AD 271 to 840 . The warm period from AD 1 to 200 corresponded to the Rome climatic optimum, while the cold period from AD 201 to 550 corresponded to the first part of the Dark Age Cold Period. However, there were some differences in temperature changes between China and the Northern Hemisphere at the beginning and end of each period.

There were year-wise, decadal, and even regional differences relating to changes in humidity. The warm period experienced during the Han Dynasty was relatively wet. During this period, the number of high-rainfall years in the east comprised $87.5 \%$ of the total period (Zheng et al., 2006). The number of low-rainfall years in the west comprised $61.7 \%$ of the total period (Shao et al., 2010). During the warm period experienced at the time of the Sui and Tang dynasties, the east was partially dry, with the number of low-rainfall years comprising $56.8 \%$ of the total period. The west, conversely, was partially wet, with the number of high-rainfall years comprising $57.3 \%$ of the total period. Although the humidity of this period fluctuated slightly, it rarely exceeded the normal level.

During the first cold period (AD 181-540), the whole country was partially dry. In the east, $55.8 \%$ of the year was partially dry, and the southern and northern regions were both dry. In the west, $65.3 \%$ of the year was partially dry. During the second cold period (AD 761-910), the east was partially dry, and the number of low-rainfall years comprised $65.3 \%$ of the period. The west was partially wet, with the number of high-rainfall years comprising $56 \%$ of the period.

\subsubsection{Ethnic wars and climate change}

On a centennial or longer timescale, no correlation was found between wars and climate change (Fig. 2, Table 3). However, in terms of the spatial variable, wars between farmers and nomadic tribes were associated with climate changes (Figs. 2i and 3). During warm periods, the battlefields were mostly distributed over northern areas (at an average latitude of $38.92^{\circ} \mathrm{N}$ ). During cold periods, the battlefields were located in areas at an average latitude of $34.66^{\circ} \mathrm{N}$ (south of the farming-grazing transitional zone). The conflicts that erupted between nomadic and farming groups occurred in some areas that are sensitive to climate change.

On a decadal timescale, a warm climate was associated with a high incidence of wars, while a cold climate was conversely associated with a low incidence of wars. The Pear- son correlation coefficient between the frequency of wars and country-level temperature variations was 0.293 (the correlation was significant (two-tailed) at the 0.01 level). During the second warm period (AD 541-760), the correlation coefficient was 0.571 , with a correlation that was significant (two-tailed) at the 0.01 level. During decades of countrywide temperature variations above or equal to around $0^{\circ} \mathrm{C}$, the average war frequency was 4.3 wars decade $^{-1}$. Conversely, during decades of countrywide temperature variations of around $0{ }^{\circ} \mathrm{C}$, the average frequency of wars was 2.6 wars decade ${ }^{-1}$. The average variation in temperature was $0.1^{\circ} \mathrm{C}$ during decades characterized by four or more wars. Of the 18 high-incidence periods of wars, 13 (72\%) of wars broke out during warm periods, with average temperature variations of $0.28^{\circ} \mathrm{C}$. Statistical analysis revealed that $20.6 \%$ of the warm periods were also high-incidence periods of war.

The proportion of farming groups as initiators of war remained low, showing no significant correlation with temperature change. Conversely, nomadic groups were consistently the aggressors. However, during cold decades, the proportion of farming groups that initiated wars increased (Table 4). The chances of victory for farming groups increased especially during warm periods. A positive correlation existed between temperature variations and the proportion of farmers' victories, the correlation coefficient being 0.173 (the correlation was significant at the 0.1 level). However, during cold periods, the chances of victory in war were almost the same for the two groups (Table 4). In short, during warm decades, a large proportion of wars were initiated by nomadic groups, and farming groups defended themselves effectively. During cold decades, the proportions of wars initiated by the two sides were similar, and the proportion of wars won by farming groups decreased.

On a decadal timescale, there was no significant correlation between the frequency of wars and the dry-wet series. During decades when the east experienced less rainfall, the proportion of wars initiated by farming groups increased, but the proportion of their victories was not high (Table 4). Conversely, during decades when the east experienced higher rainfall, the number of wars initiated by farming groups was lower, but the proportion of their victories increased. During dry and cold periods, farming groups were tended to initiate wars, but their chances of victory were reduced.

\section{Discussion}

\subsection{Reasons for the impact of climate change on wars between farming and nomadic groups}

Our finding that wars were more prevalent during warmer periods differ from those made by Zhang et al. (2006), who reported that wars were more frequent during cold periods than during warm periods. One possible reason for this is that our study only examined the frequency of wars between 
Table 3. Ethnic wars in cold and warm periods on a centennial timescale.

\begin{tabular}{|c|c|c|c|c|c|}
\hline Stage & $\begin{array}{l}\text { Cold-warm } \\
\text { phase }\end{array}$ & Regional wet-dry phase & $\begin{array}{l}\text { Average of } \\
\text { war frequency } \\
\text { per decade }\end{array}$ & $\begin{array}{l}\text { Proportion of } \\
\text { wars initiated } \\
\text { by farming } \\
\text { groups }\end{array}$ & $\begin{array}{l}\text { Proportion of } \\
\text { wars won by } \\
\text { the nomadic } \\
\text { groups }\end{array}$ \\
\hline $200 \mathrm{BC}-\mathrm{AD} 180$ & Warm & $\begin{array}{l}\text { Eastern China (wet), north } \\
\text { (drought) and south (flood); } \\
\text { western China (dry) }\end{array}$ & 4 & $21.1 \%$ & $71.8 \%$ \\
\hline AD $181-540$ & Cold & All of China (dry) & 3.6 & $38.2 \%$ & $43.5 \%$ \\
\hline AD 541-760 & Warm & $\begin{array}{l}\text { Eastern China (dry), North } \\
\text { (drought) and south (flood); } \\
\text { western China (wet) }\end{array}$ & 3.6 & $40.5 \%$ & $69.6 \%$ \\
\hline AD 761-910 & Cold & $\begin{array}{l}\text { Eastern China (dry); } \\
\text { western China (wet) }\end{array}$ & 1 & $13.3 \%$ & $100 \%$ \\
\hline
\end{tabular}

Table 4. Ethnic wars with climate change on a decadal timescale.

\begin{tabular}{llll}
\hline \multicolumn{2}{l}{ Decades under the different climatic conditions } & $\begin{array}{l}\text { Proportion of } \\
\text { wars initiated } \\
\text { by the farming } \\
\text { groups }\end{array}$ & $\begin{array}{l}\text { Proportion of } \\
\text { wars won by } \\
\text { the farming } \\
\text { groups }\end{array}$ \\
\hline $\begin{array}{l}\text { Decades } \\
\text { according to the } \\
\text { temperature }\end{array}$ & $\begin{array}{l}\text { Decades with the temperature } \\
\text { variations being above or equal to around } 0{ }^{\circ} \mathrm{C} \\
\text { Decades with the temperature } \\
\text { variations being lower than around } 0{ }^{\circ} \mathrm{C}\end{array}$ & $34.5 \%$ & $73.0 \%$ \\
\hline $\begin{array}{l}\text { Decades } \\
\text { according to the } \\
\text { humidity of the } \\
\text { east and west }\end{array}$ & $\begin{array}{l}\text { Decades with dry east and dry west } \\
\text { Decades with dry east and wet west }\end{array}$ & $45.7 \%$ & $54.6 \%$ \\
\hline
\end{tabular}

nomadic and farming groups without considering other types of war (e.g., civil wars during cold periods resulting from insufficient food). The different results may also be related to the selected temperature sequences.

Table 3 indicates that the vast majority of all wars were initiated by nomadic groups. However, farming groups achieved more victories. Further, the locations of key battlegrounds also changed as climate change. This raises questions of why these changes occurred and what the role of the climate was. These are addressed below.

A first point to consider is the strong dependence of the nomadic economy on agricultural products. Although there is some demand for livestock products within an agricultural economy, considerable differences exist between nomads and agriculturalists. The economic stability of northern nomadic and agriculturalist groups differed greatly. The nomadic economy relied heavily on nature and applied few technologies for the production of goods. Moreover, their simple socioeconomic structure was more vulnerable to natural disasters. These differences between the two groups resulted in an unequal but complementary relationship in their productive structures. Therefore, nomadic groups had to re- sort to mutual trade and wars to obtain agricultural products and crafts from farmers, making nomadic groups the primary initiators of wars. For nomadic groups, the purpose of waging war was to expand commodity circulation channels and ensure a continuous supply of agricultural products. Contrasting with agriculturalists, one of the important characteristics of nomadic groups during the cold weapon era was their combination of military activity and production. Skills acquired through routine daily activities provided nomadic groups with advantages when fighting on horseback and shooting accurately with bows and arrows; these advantages were not available to farming groups (Zhao and $\mathrm{Yu}$, 2013). They launched these wars not to acquire large territories and cities but rather to procure a variety of agricultural products and wealth. Plundering during an attack and quickly withdrawing afterwards became the effective strategy of acquiring wealth and a motivating force among nomadic groups (Cui, 2011). Therefore, these groups often initiated wars. Nomadic groups traditionally respected military force and greatly valued bravery. During warm periods when they were strong, they waged predatory and expansionary wars in the Central Plain (Ma, 2011). 
A second consideration is that a warm climate provided good environmental conditions for economic development within both groups. Good economic conditions for nomadic groups could enhance their strength against farming groups, while also providing them with a solid material foundation for waging wars (Wu et al., 2009). During cold periods, the strength of both groups was weakened to some extent, while extreme cold undermined the ability of nomads to attack by affecting and inhibiting their livestock (especially horses). The two groups compromised during cold periods. In the case of warm climate conditions, livestock proliferated, more than doubling their numbers owing to the abundant precipitation and consequent availability of lush grass (Xiao, 1972). An examination of historical vicissitudes affecting nomadic groups reveals that good climatic conditions were associated with a rapid rise of nomadic empires, bolstered by strong horses and armies (Wu et al., 2009). Moreover, populations increased rapidly during warm periods, and the requirement for life necessities led to wars. It is well known that China's monsoon climate can be typically warm and wet or cold and dry during the same period. During warm and wet periods, nomads enjoyed good conditions and had relatively few natural disasters to contend with. Consequently, populations tended to increase rapidly. Nomadic groups pursued a goal of increasing the quantity of their livestock to maintain their basic livelihoods, eventually causing the degradation of grassland in some areas and an imbalance in the grassland ecosystem (He, 2002). Some regions near the $400 \mathrm{~mm}$ rainfall line were transition areas, constituting a semi-arid ecological transition zone. Based on the feasibility of agricultural and nomadic occupations in these regions, competition over these areas intensified the conflict between the two groups. Among nomadic groups, there was an increase in subsistence requirements and demands for food, cloth, and other agricultural products, as necessary supplements that could only be obtained from farming groups (Wei, 2011). Shang (2006), who conducted a study of the Hun population during the period of the Western Han Dynasty, found that the period when the Hun population was largest extended from the Modu period to the Junchen period. During this time, Huns often waged plundering wars against foreign groups, depriving them of large numbers of people and wealth.

A third consideration is that during cold periods, both groups (and consequently political boundaries and conflict zones) moved southward. During cold periods, both groups were weakened to some extent. However, the agricultural economy had developed and accumulated abundant supplies, so governments could regulate and control the disbursement of subsidies in disaster areas. Nevertheless, because of the homogenous nature of the nomadic economy, nomadic groups suffered more losses than agriculturalists during conditions of extreme cold. They consequently launched wars to gain more resources, such as suitable land, under the pressure of overpopulation and limited production. As a result, the main conflict areas moved southward, incrementally. The strong desire to obtain living space through victory in war also contributed to the tenacity of nomadic groups during cold periods. The continuous southward migrations and invasions of nomadic groups led to frequent wars in the Central Plain, compelling the farming groups to move to the Yangtze River basin and south of the Yangtze River. During this period, a large area of cultivated land was available to be reclaimed in southern China. Moreover, the environment in this region was more suitable for farming and human habitation (Lan and Jiang, 2005). Conditions induced by the introduction of a large labour force and advanced production technologies by farming groups who moved south promoted substantial economic development in the south, attracting more agriculturalists to migrate to this region. The decreased population in the north and the deterioration of the agricultural environment in this region increased difficulties in procuring supplies of soldiers and food. Consequently, the conflict areas also moved southward. Conversely, warm climatic conditions facilitated the economic recovery of farming groups, and the gap in the military power of the two groups gradually widened. The frequency of victories of farming groups gradually increased, with the expulsion of nomadic groups from the Central Plain, and the main conflict zone gradually moved back to the north.

\subsection{Other factors influencing wars between the farming and nomadic groups}

Evidently, there were many factors that influenced wars between farming and nomadic groups. The climate only played an indirect role in these wars, for example, producing constraints on regional productivity. Consequently, the climate provided an environmental backdrop for the wars.

Many social and economic factors directly affected the wars. Social instability was one risk factor. For example, during $185 \mathrm{BC}-\mathrm{AD} 219$, for which a total of 98 flood disasters are recorded, extensive flooding of farming areas spread to many other areas. The Han government's failure to completely solve the serious consequences of the flood led to intensified social conflicts (Duan, 2002). Consequently, this was a good time for nomadic groups to launch attacks. However, there are fewer records for periods of social instability or dynastic succession.

It should be noted that conflict was not the only interaction between the two groups - peace also existed between them. Peaceful dealings, for example, marriages for the sake of peace, termed He-Qin, ${ }^{3}$ could reduce incidences of war. This practice mainly occurred during the time of the Han Dynasty. The statistics show that He-Qin occurred a total of 37 times during the periods of the Western and Eastern Han dynasties, mainly in the $150 \mathrm{~s} \mathrm{BC}, 110 \mathrm{~s} \mathrm{BC}, 50 \mathrm{~s} \mathrm{BC}, \mathrm{AD} 50 \mathrm{~s}$, AD 190s, which were warm periods. During this period, the

\footnotetext{
${ }^{3}$ Some feudal dynasties made peace through marital alliances with the rulers of minority nationalities in border areas.
} 
frequency of wars between farming and nomadic groups was reduced. During the Han dynasties, the correlation between the frequencies of He-Qin and wars was high, with a correlation coefficient of -0.733 . The correlation was significant (two-tailed) at the 0.01 level.

\section{Conclusions}

The reasons for changes in group relations are diverse and complex, influenced by political, economic, social, and cultural factors. However, climate change also plays a role in promoting change. From the period of the Western Han Dynasty to that of the Tang Dynasty, climate change influenced the relationship between nomadic and farming groups in a number of ways.

Wars between nomadic and farming groups regularly occurred. On a centennial timescale, there was no significant correlation between the number of wars and climate change. However, on a decadal timescale, a warm climate corresponded to a high incidence of wars, while cold periods corresponded to a low incidence of wars.

Overall, the majority of the wars were initiated by nomadic groups. This reflects the nomads' vulnerability, and their dependence on the farming economy rather than bearing a close relationship to climate change. However, during warm periods, most of the wars were won by farming groups, reflecting their economic strength. However, during cold periods, both sides won almost the same number of wars. The conflicts between the two groups mainly took place in the Hexi Corridor; the Loess Plateau, south of the Yellow River and north of the Qin Ling; and in the North China Plain. Wars primarily occurred either at the territorial boundaries of the two groups or within the nomadic groups' territories. As the temperature decreased, the battlefields expanded southward into farming areas.

The influence of climate change on wars between nomadic and farming groups can be examined based on the following four considerations. First, excessive population growth within nomadic groups, against the background of a warm climate, could have enhanced their desire to procure the essential means of subsistence, leading to wars. Second, warm climates provided a solid material foundation for nomadic and farming groups, contributing, especially, to improving the productivity of nomadic groups. Moreover, compared with cold periods, the fighting strength of both groups was enhanced during warm periods. Third, the nomadic economy was strongly dependent on the agricultural economy, with plundering during wars providing a low-cost means of obtaining high returns. Lastly during cold periods, agriculturalists moved southward and began to develop regions south of the Yangtze River. During this period, nomadic groups occupied the Central Plain, resulting in changes in the territorial boundaries of particular groups and consequently of conflict areas.
We conclude with some further research prospects. As there are a limited number of documents and quantitative indices, proxy indicators and criteria other than war-related data are required to gain an in-depth understanding of group relations, and especially of the groups' power and confrontations.

Moreover, we did not provide complete coverage of the 2000-year period examined in other papers, focussing instead on the period 206 BC-AD 906. Consequently, there are temporal limitations that impact on our conclusions about their relationships. The construction of the sequence also needs to be further extended. After the Tang Dynasty, China's economic centre shifted to the south, while the north remained the political centre. We suspect that ethnic relations may have changed as a consequence.

This case study revealed that the socioeconomic impacts of climate change differ regionally and for different aspects. In ancient China, peasant uprisings were more frequent during colder periods, and ethnic conflicts were a more serious concern during warmer periods. These results may indicate that multiple mechanisms contribute to the observed relationships and that different mechanisms dominate in different contexts. It seems likely that climatic changes influence wars through multiple pathways. Further research should aim to identify these mechanisms.

Acknowledgements. This study was supported by the National Natural Science Foundation of China (Grant No. 41371201 and No. 41430528 ). We thank all reviewers for valuable comments.

Edited by: D. Fleitmann

\section{References}

Buhaug, H., Gleditsch, N. P., and Theisen, O. M.: Implications of Climate Change for Armed Conflict, Working paper, Social Dimensions of Climate Change workshop, 5-6 March 2008, Washington, DC, USA, World Bank, Social Development Department, available at: http://siteresources. worldbank.org/INTRANETSOCIALDEVELOPMENT/

Resources/SDCCWorkingPaper_Conflict.pdf (last access: 15 May 2015), 2008.

CNA: National Security and the Threat of Climate Change, available at: http://securityandclimate.cna.org/ (last access: 10 May 2015), 2007.

Christiansen, B. and Ljungqvist, F. C.: The extra-tropical Northern Hemisphere temperature in the last two millennia: reconstructions of low-frequency variability, Clim. Past, 8, 765-786, doi:10.5194/cp-8-765-2012, 2012.

Chu, G. Q., Sun, Q., Wang, X. H., Liu, M. M., Lin, Y., Xie, M. M., Shang, W. Y., and Liu, J. Q.: Seasonal temperature variability during the past 1600 years recorded in historical documents and varved lake sediment profiles from northeastern China, Holocene, 22,785-792, 2012. 
Chu, K. C.: The preliminary research on climate change in China of past five thousand years, Sci. China Ser. A, 2, 15-38, 1973 (in Chinese).

Collier, P. and Hoeffler, A.: Resource Rents, Governance and Conflicts, J. Conflict Resolut., 49, 625-633, 2005.

Cui, Y.: Study on Ancient Chinese Wars in the View of Agricultural and Nomadic Husbandry, M.S. thesis, Northwest A\&F University, Yang Ling, China, 17-19, 2011 (in Chinese).

Duan, W.: The Flood Disasters in the Han Dynasty, Managing Measures to the Yellow River and The Reliefing Measures, M.S. thesis, Capital Normal University, Beijing, China, 1-4, 2002 (in Chinese).

Ge, Q., Hao, Z., Zheng, J., and Shao, X.: Temperature changes over the past $2000 \mathrm{yr}$ in China and comparison with the Northern Hemisphere, Clim. Past, 9, 1153-1160, doi:10.5194/cp-9-11532013, 2013.

Ge, Q. S., Zheng, J. Y., Fang, X. Q., Man, Z. M., Zhang, X. Q., Zhang, P. Y., and Wang, W.-C.: Winter half-year temperature reconstruction for the middle and lower reaches of the Yellow River and Yangtze River, China, during the past 2000 years, Holocene, 13, 933-940, 2003.

Ge, Q. S., Zheng, J. Y., Hao, Z. X., Shao, X. M., Wang, W.-C., and Luterbacher, J.: Temperature variation through 2000 years in China: An uncertainty analysis of reconstruction and regional difference, Geophys. Res. Lett., 37, 03703, doi:10.1029/2009GL041281, 2010.

Guo, M.: The Historical Atlas of China, Cartographic Publishing House, Beijing, China, 1996 (in Chinese).

Gribbin, J. G.: Climatic change in China over the past 5000 years, Nature, 246, 375-376, 1973.

He, W.: Farming and Nomadic: The Two Types of Economy Culture in Ancient China, J. Northwest Minorities University (Social Sciencees), 1, 100-101, 2002 (in Chinese).

Held, I. M., Delworth, T. L., Lu, J., Findell, K. L., and Knutson, T. R.: Simulation of Sahel Drought in the 20th and 21st Centuries, P. Natl. Acad. Sci. USA, 103, 1152-1153, 2006.

Hendrix, C. S. and Glaser, S. M.: Trends and triggers: Climate, climate change and civil conflict in sub-Saharan Africa, Polit. Geogr., 26, 695-715, 2007.

Hinsch, B.: Climate change and history in China, J. Asian Hist., 22, 131-159, 1998.

Homer-Dixon, T. F., Boutwell, J. H., and Rathjens, G. W.: Environmental Change and Violent Conflict, Sci. Am., 268, 38-45, 1993.

Hong, Y. T., Liu, D. S., Jiang, H. B., Zhou, L. P., Beer, J., Hong, B., Zhou, Y. X., Li, H. D., Leng, X. T., Qin, X. G., Wang, Y., Lin, Q. H., and Zeng, Y. Q.: Evidence for solar forcing of climate variation from $\delta 180$ of peat cellulose, Sci. China Ser. D, 43, $217-$ 224,2000

Hsiang, S. M., Burke, M., and Miguel, E.: Quantifying the Influence of Climate on Human Conflict, Science, 341, 1235367, doi:10.1126/science.1235367, 2013.

Lan, Y. and Jiang, L.: On the Climate Affecting Chinese Political and Economical Structure, Journal of Qinghai Nationalities Institute, 31, 45-46, 2005 (in Chinese).

Ljungqvist, F. C.: A new reconstruction of temperature variability in the extra-tropical Northern Hemisphere during the last two millennia, Geogr. Ann. A, 92, 339-351, 2010.
Loehle, C.: A 2000-year global temperature reconstruction based on non-tree ring proxies, Energy and Environment, 18, 1049-1058, 2007.

Loehle, C. and McCulloch, J. H.: Correction to: A 2000-year global temperature reconstruction based on non-tree ring proxies, Energy and Environment, 19, 93-100, 2008.

Ma, Y.: National Relations and Regularities between Northern Nomadism and Southern Agriculture in History, Journal of Xi'an University of Arts and Science (Social Sciences Edition), 14, 4546, 2011 (in Chinese).

Mann, M. E., Zhange, Z. H., Hughes, M. K., Bradley, R. S., Miller, S. K., Rutherford, S., and Ni, F.: Proxy-based reconstructions of hemispheric and global surface temperature variations over the past two millennia, P. Natl. Acad. Sci. USA, 105, 13252-13257, 2008.

Mann, M. E., Zhange, Z. H., Rutherford, S., Bradley, R. S., Hughes, M. K., Shindell, D., Ammann, C., Faluveqi, G., and Ni, F.: Global signatures and dynamical origins of the Little Ice Age and medieval climate anomaly, Science, 326, 1256-1260, 2009.

Maxwell, J. W. and Reuveny, R.: Resource Scarcity and Conflict in Developing Countries, J. Peace Res., 37, 301-322, 2000.

McShane, B. B. and Wyner, A. J.: A statistical analysis of multiple temperature proxies: Are reconstructions of surface temperatures over the last 1000 years reliable, Ann. Appl. Stat., 5, 5-44, 2011.

Shang, X.: Tentative Analysis of Hun's Population Change in Western Han Dynasty, Population and Economics, 2, 64-65, 2006 (in Chinese).

Shao, X. M., Xu, Y., Yin, Z. Y., Liang, E., Zhu, H., and Wang, S.: Climatic implications of a 3585-year tree-ring width chronology from the northeastern Qinghai-Tibetan Plateau, Quaternary Sci. Rev., 29, 2111-2122, 2010.

Shu, T. and Xiao, M.: Accounts of ancient Chinese northern nomadic culture since 1980, The Western Regions Studies, 2, 116124, 2008 (in Chinese)

Tan, M., Liu, D.-S., Qin X.-G., Zhong, H., Li, T.-Y., Zhao, S.-S., Li, H.-C., Lv, J.-B., and Lu, X.-Y.: Preliminary study on the data from microbanding and stable isotopes of stalagmites of Beijing Shihua cave, Carsologica Sinica, 16, 1-10, 1997 (in Chinese).

Tan, Q.: Historical Atlas of China, Cartographic Publishing House, Beijing, China, 1982 (in Chinese).

The Chinese military history editorial board: Chronology of Wars in Chinese History, Chinese Peoples Liberation Army Publishing House, Beijing, China, 2003 (in Chinese).

Tol, R. S. J. and Wagner, S.: Climate change and violent conflict in Europe over the last millennium, Climatic Change, 99, 65-79, 2010.

Wang, H.: The Relationship between the Migrating South of the Nomadic Nationalities in North China and the Climatic Changes, Scientia Gelgraphica Sinica, 16, 274-279, 1996 (in Chinese).

Webster, D.: Warfare and the Evolution of the State: A Reconsideration, Am. Antiquity, 40, 464-470, 1975.

Wei, J.: On the Ancient Farming and Nomadic Economy, China Collective Economy, 16, 80-81, 2011 (in Chinese).

Wu, W., Ge, Q., Zheng, J., Zhou, Y., and Hu, Y.: Possible Role of Climate Change in the Mongol Westward Conquests, Quaternary Sciences, 29, 729-730, 2009 (in Chinese).

Xiao, Q.: Examination on the Various Causes of Southward Invasion of Northern Asia Nomadic, Shin-Huo Monthly, 1, 609-619, 1972. 
Zhang, D. D., Jim, C. Y., Lin, G. C.-S., He, Y. Q., Wang, J. J., and Lee, H. F.: Climatic Change, Wars and Dynastic Cycles in China over the Last Millennium, Climatic Change, 76, 459-477, 2006.

Zhang, W.: Historical documents inheritance in historic change, Journal of Southern Yangtze University (Humanities and Social Sciences), 1, 60-63, 2002 (in Chinese).

Zhao, Y. and Yu, W.: Combination of Military and Production Resource Allocation and Size of the Nomad and Farming Nationality, Research on Institutional Economics, 2, 137-146, 2013 (in Chinese).
Zheng, J., Wang, W.-C., Ge, Q., Man, Z., and Zhang, P.: Precipitation Variability and Extreme Events in Eastern China during the Past 1500 Years, Terr. Atmos. Ocean. Sci., 17, 579-592, 2006. 